\title{
Differential Expression of Autophagy-Related Marker (Beclin-1) in Relation to Clinicopathological Parameters in Different Breast Cancer Molecular Subtypes
}

\author{
RANIH Z. AMER, M.D.; SHAIMAA M.N. EL-ZAMLY, M.D.; HALA A. AGINA, M.D. and \\ MONA A.M. ABO EL-KHAIR, M.Sc.
}

The Department of Pathology, Faculty of Medicine, Benha University

\begin{abstract}
Background: Beclin-1 plays a vital role in the vesicle nucleation in the process of autophagy and has an important role in development, tumorigenesis, and neurodegeneration.

Aim of Study: Study the role of beclin-1 and correlate the degree of its expression with available clinic-pathological data in different molecular types of breast cancer.

Material and Methods: Immunohistochemistry was performed to examine the expression of Beclin-1 different molecular subtypes of invasive ductal carcinoma and correlating it to clinicopathological parameter.

Results: The expression of Beclin-1 was decreased in breast cancer in relation to normal tissue. High expression was significantly correlated with tumor grade, distant metastasis and stage. All the cases with high Beclin-1 expression were triple negative breast cancer cases.

Conclusions: Triple negative breast cancer cases showed the highest tumor stage, grade, distant metastasis and beclin1 expression suggesting that the overexpression of Beclin 1 may by itself confer an aggressive biological course. It could be a therapeutic target.
\end{abstract}

Key Words: Breast carcinoma - Molecular subtypes - Autophagy, Beclin-1.

\section{Introduction}

BREAST cancer is considered the most frequently diagnosed cancer and the leading cause of cancer mortality among women in both developed and developing countries [1]. In Egypt, the condition is even worse; the incidence exceeded the world records, where breast cancer accounts for about $20 \%$ of all cancers and $32.04 \%$ of female cancers diagnosed between the years 2008-2011 [2]. Despite recent advances in treatment protocols, it still has unfavorable prognosis with $29 \%$ mortality and 3.7 :

Correspondence to: Dr. Ranih Z. Amer, The Department of Pathology, Faculty of Medicine, Benha University
1 incidence to mortality ratio [3]. This is probably due to that $12 \%$ of patients present with distant metastasis at time of diagnosis [4,5]

Breast cancer is classified according to hormone receptor status (estrogen receptor (ER) status, progesterone receptor (PR) status and Her-2 neu receptor status) into four major subtypes: Luminal A, Luminal B triple positive, triple negative/basallike and HER2 enriched type [6,7].

Autophagy is a cellular component of lysosomal degradation that is subclassified as micro-autophagy, chaperone-mediated autophagy, and macroautophagy, with macro-autophagy being the most common. This system removes and recycles the dysfunctional or damaged cellular components. This is essential for cellular homeostasis [8]. The process of mammalian autophagy is divided into six principal steps: Initiation, nucleation, elongation, closure, maturation, and degradation or extrusion $[8,9]$

There are several known markers of autophagy; Among these, beclin-1 which is involved in nucleation [10], Light chain (LC) 3 which participates in autophagosome formation and elongation $[11,12]$ and p62, a scaffold protein that delivers ubiquitinated proteins to the autophagosome $[\mathbf{1 3 , 1 4}]$

Beclin- 1 gene maps to a tumor susceptibility locus on human chromosome $17 \mathrm{q} 21$ that is monoallelically deleted in up to $40-75 \%$ of cases of sporadic ovarian and breast carcinomas [15]. Beclin1 is a mammalian autophagy gene that negatively regulates tumorigenesis [10].

Previous studies showed that the expression of Beclin-1 is decreased in various human cancer types [16]. Such as cervical [17], esophageal [17], 
lung [18,19], hepatocellular carcinoma [20], as well as cutaneous melanoma [20]. However, Beclin-1 expression was reported to be increased in contrast to their normal counterparts in human colon [21] gastric [21], and pancreatic cancers [22]. The difference in beclin- 1 between different tissues may be explained by its dual function in both tumor inhibition and tumor progression. Some studies suggested that it is possible that different Beclin-1 complexes exist, and they can function at various cellular locations and under different stimuli [23] This made us interested in conducting this study to examine the immunohistochemical expression of Beclin-1 in different molecular subtypes of breast cancer.

\section{Patients and Methods}

This is a retrospective study carried upon 50 specimens of Formalin-fixed, paraffin-embedded 50 patients diagnosed with invasive breast ductal carcinoma, processed between 2013 \& 2015. Ten Normal control cases were taken from normal breast from patient underwent reduction mammoplasty. The Paraffin blocks were collected from the Pathology Department, faculty of Medicine and the Early Cancer Detection Unit, Benha University, Egypt. The clinicopathological data were collected from patient's records.

In each case, clinicopathologic data including the patient's age, tumor size, grade, lymph node status, distant metastasis, stage, hormonal status (ER, PR and Her-2 neu) status and ki 67 index, were obtained. The studied cases according to age, were classified into two groups $<50$ years and $\geq 50$ years old groups. According to the tumor size, cases were classified into 3 groups (Up to $2 \mathrm{~cm}$ ), $(>2-5 \mathrm{~cm})$ and $(>5 \mathrm{~cm})$.

Histopathological study: From each selected formalin-fixed, paraffin-embedded block three sections, five microns thick were prepared. One section was stained by conventional Hematoxylin and Eosin (H\&E) stain. Reviewing of histopathological type according to WHO classification (2012) and exact grading according to Elston/Nottingham modification of Bloom-Richardson system was done. This grading system is based on 3 different features (Tubule formation, nuclear pleomorphism and mitotic count) of the cells in the tumor. Each of these features is given a score of 1 to 3 .

Molecular classification: Scoring of ER and PR: They were considered positive if $1 \%$ or more of tumor cells have nuclear staining of any intensity [24] while HER2 be defined as positive if $10 \%$ or more of tumor cells exhibit strong uniform mem- brane staining [25]. Accordingly, cases where classified into: Luminal A (ER-positive and/or PRpositive, HER2-negative), Luminal B (ER-positive and/or PR-positive, highly positive for Ki67 and/or HER2-positive), Triple negative/basal-like (ERnegative, PR negative \& HER2-negative), and HER2 type (ER-negative, PR-negative \& HER2positive).

Immunohistochemical study: For immunohistochemical (IHC) staining, 10\% formalin-fixed, paraffin-embedded, 4-micron tissue sections were prepared. They were immunostained for Beclin1 Rabbit polyclonal antibody at a dilution of $1: 200$. DAP was utilized as a chromogen. IHC staining was performed, using detection kit according to the manufacturer data (GeneTex International Corporation). Positive control: Internal positive control was evaluated as the presence of Beclin-1 staining was detected in epithelial cells of normal ducts of the breast.

\section{Immunohistochemical assessment:}

Expression of Beclin-1 was either cytoplasmic or nucleo-cytoplasmic. Immunohistochemical cytoplasmic staining was evaluated based on both the percentage of stained cells and the immunostaining intensity. The percentage of stained cells was graded as 0 (negative), 1 ( $<30 \%$ positive), or 2 (>30\% positive), and immunostaining intensity was graded as 0 (negative), 1 (weak), 2 (moderate), or 3 (strong). The scores for the proportion of stained cells and the staining intensity were multiplied to provide a total score: Negative (0-1), low positive (2-4), or high positive (5-6) following the study of Won KY et al., 2010 [26].

\section{Statistical analyses:}

The collected data were summarized according to the mean \pm Standard Deviation (SD), the range for quantitative data frequency, and percentage of qualitative data. Comparisons between the different study groups were carried out using the Chi-square test $(\chi)$ and Fisher Exact test (FET) to compare proportions as appropriate. One-way Analysis of Variance (ANOVA; F) was used to compare differences between more than two groups regarding parametric data. Statistical significance was accepted at $p$-value $\leq 0.05$. The statistical analysis was conducted using SPSS (version 16).

\section{Results}

\section{Patient characteristics:}

The current retrospective study was carried on 50 cases of breast ductal carcinoma while 10 benign breast specimens were included as control cases. 
According to the molecular classification; $24 \%$ of the cases were luminal A subtype, $26 \%$ of the cases were luminal B subtype, $28 \%$ of the cases were Her 2 enriched subtype and $22 \%$ of the cases were triple negative breast cancer. The relationship between the breast cancer molecular subtypes and the different clinicopathological data are shown in (Table 1). Patients with TNBC had the lowest mean age at the time of diagnosis $(p=0.02)$ (Table 1$)$.
Our results showed that there was a statistically significant correlation between the various molecular subtypes and tumor grade, lymph node metastasis, distant metastasis and tumor stage. Triple negative breast cancer showed higher tumor grade $(p=0.03)$, more lymph node metastasis $(p=0.03)$, more distant metastasis and $(p=0.001)$ higher tumor stage ( $p=0.04$ ) followed by Her- 2 enriched type and the least was luminal tumors.

Table (1): Clinicopathological data among the different molecular subtypes.

\begin{tabular}{|c|c|c|c|c|c|c|}
\hline \multirow{2}{*}{$\begin{array}{l}\text { Clinicopathological } \\
\text { data }\end{array}$} & $\begin{array}{c}\text { Luminal A } \\
(\text { no.=12) }\end{array}$ & $\begin{array}{c}\text { Luminal B } \\
\text { (no.=13) }\end{array}$ & $\begin{array}{l}\text { Her } 2 \text { enriched } \\
\text { (no.=14) }\end{array}$ & $\begin{array}{l}\text { Triple negative } \\
\text { (no.=11) }\end{array}$ & \multirow{2}{*}{ Test } & \multirow{2}{*}{$\begin{array}{c}p- \\
\text { value }\end{array}$} \\
\hline & No. $(\%)$ & No. $(\%)$ & No. $(\%)$ & No. $(\%)$ & & \\
\hline \multicolumn{7}{|l|}{ Age (years): } \\
\hline Mean \pm SD & $51.58 \pm 10.17$ & $58.77 \pm 7.47$ & $52.07 \pm 9.58$ & $45.64 \pm 11.62 * *$ & $F=3.66$ & $0.02 *$ \\
\hline Range & $(34-73)$ & $(48-70)$ & $(37-72)$ & $(30-65)$ & & \\
\hline \multicolumn{7}{|l|}{ Age groups: } \\
\hline$<50$ & $7(58.33)$ & $3(23.08)$ & $7(50)$ & $8(72.73)$ & $X^{2}=6.37$ & 0.09 \\
\hline$>50$ & $5(41.67)$ & $10(76.92)$ & $7(50)$ & $3(27.27)$ & & \\
\hline \multicolumn{7}{|l|}{ Tumor size $(\mathrm{cm})$ : } \\
\hline Mean \pm SD & $4.06 \pm 3.09$ & $3.54 \pm 2.15$ & $4.15 \pm 2.15$ & $3.12 \pm 1.15$ & $F=0.55$ & 0.65 \\
\hline Range & $1.5-10$ & $1.5-10$ & $1.5-10$ & $1.5-5$ & & \\
\hline$<2.5$ & $8(66.67)$ & $4(30.77)$ & $3(21.43)$ & $3(27.27)$ & & \\
\hline $2-5$ & $1(8.33)$ & $8(61.54)$ & $9(64.29)$ & $8(72.73)$ & FET & 0.22 \\
\hline$>5$ & $3(25)$ & $1(7.69)$ & $2(14.29)$ & 0 & & \\
\hline \multicolumn{7}{|l|}{ Tumor grade: } \\
\hline 1 & $5(41.67)$ & $1(7.69)$ & $1(7.14)$ & 0 & FET & $0.03 *$ \\
\hline 2 & $4(33.33)$ & $7(53.85)$ & $7(50)$ & $2(18.18)$ & & \\
\hline 3 & $3(25)$ & $5(38.46)$ & $6(42.86)$ & $9(81.82)$ & & \\
\hline \multicolumn{7}{|l|}{ Lymph node } \\
\hline \multicolumn{7}{|l|}{ metastases: } \\
\hline Negative & $5(41.67)$ & $4(30.77)$ & $4(28.57)$ & 0 & FET & $0.03 *$ \\
\hline $1-3$ & $4(33.33)$ & $6(46.15)$ & $2(14.29)$ & $1(9.09)$ & & \\
\hline $4-9$ & $2(16.67)$ & $2(15.38)$ & $5(35.71)$ & $3(27.27)$ & & \\
\hline$>10$ & $1(8.33)$ & $1(7.69)$ & $3(21.43)$ & 7 (63.64) & & \\
\hline \multicolumn{7}{|l|}{ Stage: } \\
\hline I & $4(33.33)$ & $2(15.38)$ & $2(14.29)$ & 0 & FET & $0.04 *$ \\
\hline II & $5(41.67)$ & $5(38.46)$ & $1(7.14)$ & $2(18.18)$ & & \\
\hline III & $3(25.0)$ & $3(23.08)$ & $7(50)$ & $3(27.27)$ & & \\
\hline IV & 0 & $3(23.08)$ & $4(28.57)$ & $6(54.55)$ & & \\
\hline \multicolumn{7}{|l|}{ Distant metastases: } \\
\hline Absent & $12(100)$ & $12(84.62)$ & $10(71.43)$ & $3(27.27)$ & FET & $0.001 * *$ \\
\hline Present & 0 & $1(15.38)$ & $4 \quad(28.57)$ & $8(72.73)$ & & \\
\hline
\end{tabular}

* Means statistically significant.

*** Means statistically highly significant. 
Correlation between the expression of Beclin1 and the clinicopathologicalparameters (Table 2):

Expression of (Beclin-1) was correlated with different clinicopathological findings of the studied cases. All 10 benign breast lesions specimens taken as control cases showed high positive expression for beclin- 1 . The current study revealed that $66 \%$ of cases were negative for Beclin1, 28\% cases were low positive, and $6 \%$ percent of cases showed high positive cytoplasmic staining. We found that there was a decrease in cytoplasmic Beclin-1 expression in tumor tissue in relation to the adjacent normal tissue except for in approximately $34 \%$ of cases. Out of the positive cases; Most of the positive cases $(90 \%)$ showed cytoplasmic staining while only $10 \%$ showed both nuclear and cytoplasmic staining.
There was a statistically significant positive correlation between Beclin-1 and grade ( $p$-value $=0.02)$, distant metastasis $(p$-value $=0.02)$, stage $(p$-value $=0.03)$ and molecular subtypes of IDC ( $p$ value $<0.001)$. The present study showed no statistically significant correlation between Beclin1 and age of patient ( $p$-value $=0.29$ ), tumor size $(p$-value $=0.90)$ and lymph node metastasis $(p$-value $=0.06$ ).

Expression of Beclin-1 according to molecular subtypes:

The expression of autophagy related protein Beclin-1 in relation to different molecular subtypes is shown in Table (2). The TNBC cases had the highest positive expression, where all the cases that showed strong cytoplasmic positivity were TNBC $(p=0.03)$. The least positivity was detected in Luminal Type A.

Table (2): Relation between Beclin-1 expression and clinicopathological parameters.

\begin{tabular}{|c|c|c|c|c|c|}
\hline \multirow{3}{*}{ Variable } & \multicolumn{3}{|c|}{ Beclin-1 expression } & \multirow{3}{*}{ Test } & \multirow{3}{*}{$\begin{array}{c}p- \\
\text { value }\end{array}$} \\
\hline & \multirow{2}{*}{$\begin{array}{c}\begin{array}{c}\text { Negative } \\
\text { (no.=33) }\end{array} \\
\text { No. }(\%)\end{array}$} & \multirow{2}{*}{$\begin{array}{c}\begin{array}{c}\text { Low positive } \\
\text { (no.=14) }\end{array} \\
\text { No. }(\%)\end{array}$} & \multirow{2}{*}{$\begin{array}{c}\begin{array}{c}\text { High positive } \\
\text { (no.=3) }\end{array} \\
\text { No. }(\%)\end{array}$} & & \\
\hline & & & & & \\
\hline \multicolumn{6}{|l|}{ Age: } \\
\hline Mean \pm SD & $53.97 \pm 9.65$ & $49.07 \pm 11.33$ & $48.67 \pm 15.27$ & $\mathrm{~F}=1.28$ & 0.29 \\
\hline $\begin{array}{l}\text { Kange } \\
<50 \mathrm{y}\end{array}$ & $15(45.45)$ & $9(64.29)$ & $1(33.33)$ & FET & 0.50 \\
\hline$>50 y$ & $18(54.55)$ & $5(35.71)$ & $2(66.67)$ & & \\
\hline \multicolumn{6}{|l|}{ Tumor size $(\mathrm{cm})$ : } \\
\hline MeantSD & $3.8 \pm 2.32$ & $3.82 \pm 2.26$ & $2.7 \pm 0.52$ & $\mathrm{~F}=0.34$ & 0.71 \\
\hline Range & $(1.5-10)$ & $(1.5-10)$ & $(2.1-3)$ & & \\
\hline$<2.5^{\circ}$ & $11(33.33)$ & $6(42.86)$ & $1(33.33)$ & & \\
\hline $2-5$ & $18(54.55)$ & $6(42.86)$ & $2(66.67)$ & FET & 0.90 \\
\hline & $4(12.12)$ & $2(14.29)$ & 0 & & \\
\hline \multicolumn{6}{|l|}{ Tumor grade: } \\
\hline 1 & $7(21.21)$ & 0 & 0 & FET & $0.02 *$ \\
\hline 2 & $16(48.48)$ & $4(28.57)$ & 0 & & \\
\hline 3 & $10(30.3)$ & $10(71.43)$ & $3(100)$ & & \\
\hline \multicolumn{6}{|l|}{ Lymph node } \\
\hline $\begin{array}{l}\text { metastases: } \\
\text { Negative }\end{array}$ & $10(30.3)$ & $3(21.43)$ & 0 & FET & 0.06 \\
\hline $1-3$ & $11(33.33)$ & $2(14.29)$ & 0 & & \\
\hline $4-9$ & $8(24.24)$ & $4(28.57)$ & 0 & & \\
\hline$>10$ & $4(12.12)$ & $5(35.71)$ & $3(100)$ & & \\
\hline \multicolumn{6}{|l|}{ Stage: } \\
\hline I & $8(24.24)$ & 0 & 0 & FET & $0.03 *$ \\
\hline II & $7(21.21)$ & $6(42.86)$ & 0 & & \\
\hline III & $10(30.3)$ & $6(42.86)$ & 0 & & \\
\hline IV & $8(4.24)$ & $2(14.29)$ & $3(100)$ & & \\
\hline \multicolumn{6}{|c|}{ Distant metastases: } \\
\hline Absent & $24(72.73)$ & $12(85.71)$ & $1(33.33)$ & FET & $0.02 *$ \\
\hline Present & $9(27.27)$ & $2(14.29)$ & $2(66.67)$ & & \\
\hline \multicolumn{6}{|c|}{ Molecular subtypes: } \\
\hline Luminal A & $11(33.33)$ & $1(7.14)$ & 0 & FET & $0.03 *$ \\
\hline Luminal B & $11(33.33)$ & $2(14.28)$ & 0 & & \\
\hline Her-2 enriched & $11(30.3)$ & $3(21.43)$ & 0 & & \\
\hline TNBC & 0 & $8(57.14)$ & $3(100)$ & & \\
\hline
\end{tabular}

*: Statistically significant 


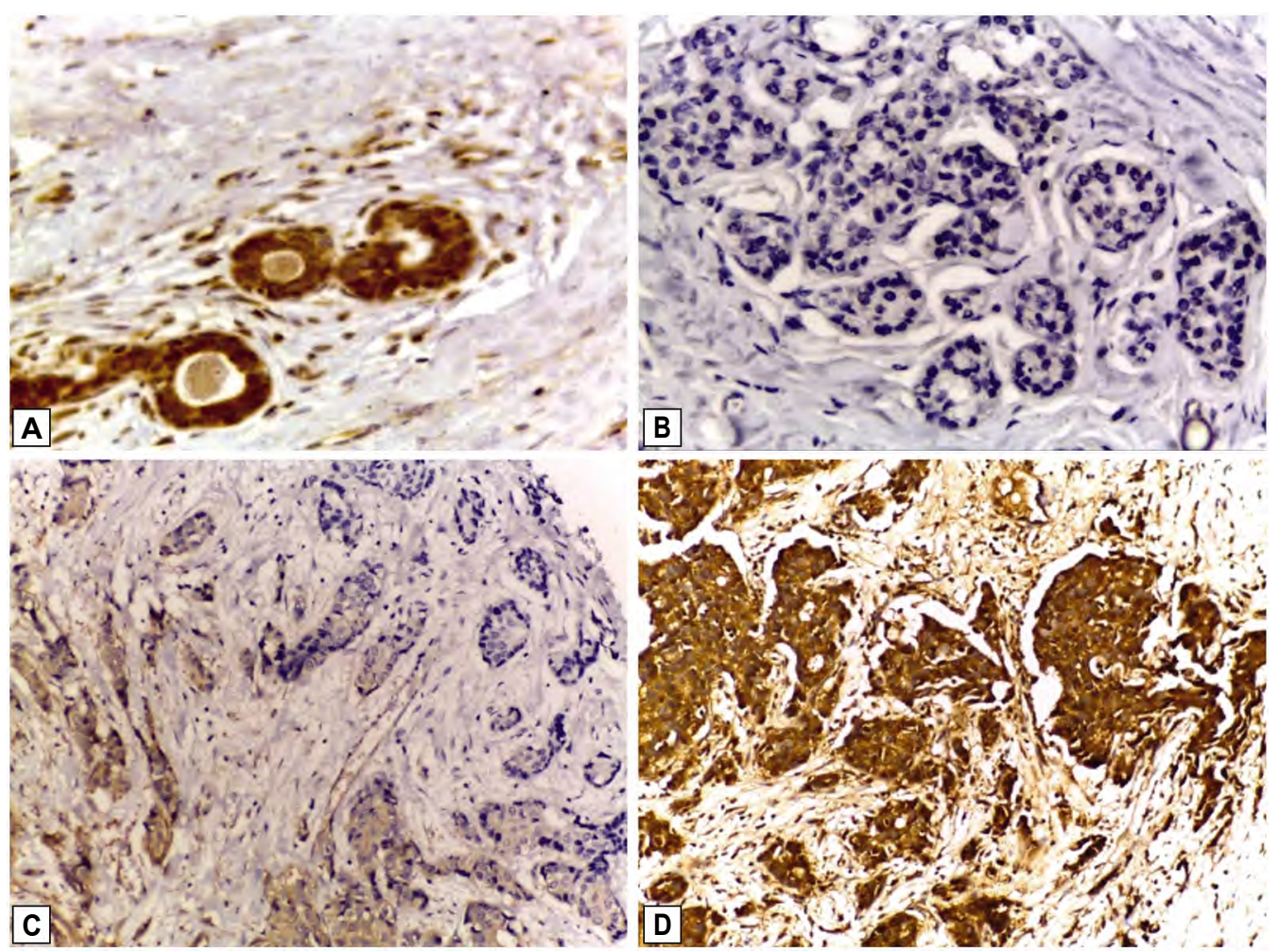

Fig. (1): Benign breast lesion showing high positive expression of Beclin-1 (A): negative expression of beclin-1 in luminal type A cancer (B): Low expression of Beclin-1 in Luminal type B (C): Strong expression of Beclin-1 in TNBC (D).

\section{Discussion}

In this study we investigated the immunohistochemical expression of autophagy related marker, Beclin-1 in different molecular subtypes of breast cancer and its correlation with the clinicopathological parameters. There are limited study relating the differential expression of autophagy related markers to clinicopathological and molecular subtypes of breast cancer. Invasive breast cancers are heterogeneous, showing distinct molecular, pathologic features and biologic behavior. Currently, the morphologic classification, histologic grade, status of estrogen receptor (ER), progesterone receptor (PR), and human epidermal growth factor receptor-2 (HER2), along with tumor stage, are used to guide clinical management [6] .

Our study showed that the TNBC cases showed higher tumor grade, stage, Lymph node metastasis and distant metastasis followed by Her- 2 enriched type and the least was luminal tumors as shown in (Table 1). TNBC cases showed high nuclear pleomorphism and a high mitotic index. These results were consistent with the results provided by Bauer KR et al., [27] and Sotiriou C et al., [28] who concluded that even small-sized triple negative breast tumors present a high incidence of lymph node involvement [28]. Also, matching the results provided by Rakha and colleagues [29] who proved that triple-negative phenotype was associated with distant metastasis and showed a specific pattern with high frequency of spinal cord, meninges, brain, liver and lung metastases. Visceral metastases are more common in Her-2 enriched type [30], while bone metastases are a common pattern in luminal tumors [31]. Based on previous studies that most of triple negative cancers (83\%) contain p53 and BRCA1 gene mutations while Luminal A subtype contained only $13 \%$ mutated tumors [32,33] Previous studies had shown that mutations in the TP53 gene predict poor prognosis and are associated with poor response to systemic therapy [34, 35] this might explain the higher stage associated with TNBC in our study.

One of the mechanisms through which cancer development could be controlled is autophagy which is an important conserved catabolic process used by human cells for clearance of cytoplasmic materials, damaged organelles and aggregate-prone proteins in lysosomes. The recycling of these intracellular constituents also serves as an alternative energy source during periods of metabolic stress to maintain homeostasis and viability [36]. Recent evidence shows that autophagy provides a protective function for the tumor cells to limit 
tumor necrosis and inflammation, and to mitigate genome damage in tumor cells in response to metabolic stress [37]. Autophagy is controlled by the combination of more than 30 autophagy related genes (Atg) $[38,39]$. Beclin-1 plays a crucial role in the vesicle nucleation, the formation of the double membrane of autophagosome [40] and regulation of autophagy. It has an important role in development process, aging, diabetes, and fatty liver, and tumorgenesis, so it is regarded as a potential therapeutic target $[41,42]$. Beclin-1 gene maps to a tumor susceptibility locus on human chromosome $17 \mathrm{q} 21$. It is mono-allelically deleted in most cases of sporadic human cancers, as in $75 \%$ of ovarian and $40 \%$ of prostate cancers $[43,44]$

Some data favor the idea that it suppresses tumor development. This was based on the studies that concluded that heterozygous disruption of Beclin-1 gene in mice displays increased proliferation and increased frequency of spontaneous malignancy and mammary neoplasia $[45,46]$. Whereas other data suggest that Beclin- 1 had a tumor supporter function that enhances tumor development and protects tumor cells from cell death stimuli [47]. So, Beclin-1 had a promising prognostic indicator for disease monitoring.

The current work demonstrated that all 10 benign breast specimens showed high cytoplasmic positive expression for Beclin-1. While of cancer cases; $66 \%$ were negative and $28 \%$ were weak positive while only $6 \%$ showed strong positivity. All the strong positive cases (6\%) were TNBC. A decrease in cytoplasmic Beclin-1 expression in tumor tissue in relation to the adjacent normal tissue was observed. This supports the hypothesis that it suppresses tumor development. This was also reported in different tissues. The expression of Beclin-1 was also observed to be decreased in various human cancer types, such as hepatocellular carcinoma [20], esophageal carcinomas [48], cutaneous melanoma [49], cervical carcinoma [17] and lung cancers [19]. Also, a study held on canine mammary tumors proved that the cytoplasmic expression of Beclin-1 in cancer cells was lower than that of normal mammary glands [50]. Cell culture technique proved that Beclin 1 depletion in monolayer cultures was found to increase tumor genesis and progression [51]. However, Beclin-1 expression was reported to be increased in human colon, gastric [21], and pancreatic cancers [22] in contrast to their normal counterparts. This supports that Beclin-1 acts as a tumor suppressor gene involved in the tumor initiation step [52].
The cytoplasmic location of Beclin-1 (Fig. 1) is explained by its importance in formation of the double membrane of autophagosome in the process of autophagy and serves as a scaffold by binding to other proteins. This takes place in the cytoplasm. Beclin-1 is reported to reside in the trans Golgi network, endoplasmic reticulum and the mitochondria [53,47]. However, nuclear beclin- 1 expression is due to presence of its regulatory gene $(\mathrm{BECN}-$ 1) [54]. The shift in expression might be related to the loss of Beclin-1 gene suppressor function [55, 65]. This agrees with the results provided by Won et al., and Qu X [26,43] who stated that the Beclin1 gene is mono-allelically deleted in majority of cases of sporadic ovarian and breast carcinomas that can lead to defects in autophagy and apoptosis, contributing to tumorigenesis. Morikawa et al., [43] also reported that many breast cancer cells lack beclin- 1 expression due to a combination of monoallelic deletion and epigenetic silencing of the Beclin-1 gene.

The current study showed a statistically significant correlation between Beclin- 1 and grade of the tumor $(p$-value $=0.02)$. High positive expression of Beclin-1 was associated with grade III breast carcinoma. This agrees with the results provided by several studies $[\mathbf{5 7 , 5 8 ]}$. However, Choi and colleagues, [59] demonstrated no significant correlation between Beclin-1 and the grade of the tumor. On the other hand, other studies [26] demonstrated an inverse significant correlation between Beclin- 1 and the grade of the tumor. High tumor grade has central necrosis which stimulates autophagy and so high Beclin- 1 expression to facilitate removal of the necrotic tissue [37]. This might explain that TNBC cases show the highly positive Beclin-1 expression (Fig. 1).

Beclin- 1 is correlated with distant metastasis ( $p$-value $=0.02)$ and with high TNM stage of breast carcinoma $(p$-value $=0.03)$. This could be explained by the loss of extracellular matrix attachment and lack of appropriate matrix contact induces autophagy to promote cell survival, either during early carcinoma formation or in the later stages of dissemination and metastasis [60]. Also, autophagy tends to facilitate metastatic process by sustaining spreading cell survival and colonization at a secondary site and by inducing these cells to enter dormancy if they fail to establish stable contact with the extracellular matrix in the new environment [61]. The high expression of Beclin-1 is associated also with high stage of endometrial carcinoma [62] and gastric carcinoma [63]. The correlation between Beclin-1 expression and the advanced grade and stage of the tumor could be explained 
by the observation that Beclin-1 has a predominantly tumor suppressor function in the initial tumorgenesis phase, and a predominantly tumor supporter function thereafter [40]. There was no correlation between beclin-1 expression and tumor size or age of patient and this agrees with the study of Choi, et al., [59].

Regarding the molecular subtypes of IDC, our study reported a high statistically significant correlation between Beclin-1 expression and molecular subtype of IDC ( $p$-value <0.001). Cytoplasmic Beclin- 1 expression was lowest in luminal breast tumors. While cytoplasmic Beclin-1 expression was highest in TNBC tumors which have high tumor grade (Tables 1,2). This was in agreement with the results of several other studies $[\mathbf{5 9 , 6 4 ]}$ However, it is worth noting that allelic deletion of Beclin-1 and depressed Beclin-1 expression exist in some TNBC cell lines [65]. Our results could be explained by the higher level of hypoxia in TNBC due to central necrosis and high tumor grade than in other breast cancer subtypes. Hypoxia is a wellknown stimulus for inducing autophagy which is an adaptive metabolic response necessary to maintain homeostasis and cell survival [66]

In conclusion, Triple negative breast cancer cases showed the highest tumor stage, grade, distant metastasis and beclin- 1 expression suggesting that the overexpression of Beclin-1 may by itself confer an aggressive biological course. It could be a therapeutic target.

Declaration of conflicting interests: The author(s) declared no potential conflicts of interest with respect to the research, authorship, and publication of this article.

Funding: The authors received no financial support for the research, authorship, and publication of this article.

\section{References}

1- SIEGEL R., NAISHADHAM D. and JEMAL A.: Cancer statistics. CA. Cancer. J. Clin., 63 (1): 11-30, 2013.

2- IBRAHIM A.S., KHALED H.M., MIKHAIL N.N., BARAKA H. and KAMEL H.: Cancer incidence in egypt: results of the national population-based cancer registry program. J. Cancer. Epidemiol., 437971, 2014.

3- ZEENELDIN A.A., RAMADAN M., ELMASHAD N., FAKHR I., DIAA A. and MOSAAD E.: Breast cancer laterality among Egyptian patients and its association with treatments and survival. J. Egypt Natl. Canc. Inst., 25 (4): 199-207, 2013

4- HIRKO K.A., SOLIMAN A.S., HABLAS A., et al.: Trends in Breast Cancer Incidence Rates by Age and Stage at
Diagnosis in Gharbiah, Egypt, over 10 Years (1999-2008). J. Cancer. Epidemiol., 916394, 2013.

5- AHMED A.R.: HER2 expression is a strong independent predictor of nodal metastasis in breast cancer. J. Egypt Natl. Canc. Inst., 28 (4): 219-227, 2016.

6- BRENTON J.D., CAREY L.A., AHMED A.A. and CALDAS C.: Molecular classification and molecular forecasting of breast cancer: Ready for clinical application? J. Clin. Oncol., 23 (29): 7350-7360, 2005.

7- TANG P. and TSE G.M.: Immunohistochemical Surrogates for Molecular Classification of Breast Carcinoma: A 2015 Update. Arch. Pathol. Lab. Med., 140 (8): 806-814, 2016.

8- GALLUZZI L., BAEHRECKE E.H., BALLABIO A., et al.: Molecular definitions of autophagy and related processes. EMBO J., 36 (13): 1811-1836, 2017.

9- TOOZE S.A. and YOSHIMORI T.: The origin of the autophagosomal membrane. Nat. Cell. Biol., 12 (9): 831835,2010

10- MEI Y., GLOVER K. and SU M., SINHA S.C.: Conformational flexibility of BECN1: Essential to its key role in autophagy and beyond. Protein. Sci., 25 (10): 1767$1785,2016$.

11- KABEYA Y., MIZUSHIMA N., UENO T., et al.: LC3, a mammalian homologue of yeast Apg8p, is localized in autophagosome membranes after processing. EMBO J., 19 (21): 5720-5728, 2000

12- KWON D.H., KIM L., KIM B.W., et al.: A novel conformation of the LC3-interacting region motif revealed by the structure of a complex between LC3B and RavZ. Biochem. Biophys. Res. Commun., 490 (3): 1093-1099, 2017.

13- LI Q., HAN Y., DU J., et al.: Alterations of apoptosis and autophagy in developing brain of rats with epilepsy: Changes in LC3, P62, Beclin-1 and Bcl-2 levels. Neurosci Res., 2017.

14- LIU W.J., YE L., HUANG W.F., et al.: p62 links the autophagy pathway and the ubiqutin-proteasome system upon ubiquitinated protein degradation. Cell. Mol. Biol. Lett., 21: 29, 2016.

15- TSANG J.Y. and TSE G.M.: Is BECN1 a Target Gene of Chromosome 17q21 Alteration in Breast Cancer? EBioMedicine, 2 (3): 190-191, 2015.

16- GALLUZZI L., PIETROCOLA F., BRAVO-SAN PEDRO J.M., et al.: Autophagy in malignant transformation and cancer progression. EMBO J. 34 (7): 856-880, 2015.

17- WANG Z.H., XU L., WANG Y., CAO M.Q., LI L. and BAI T.: Clinicopathologic correlations between human papillomavirus 16 infection and Beclin 1 expression in human cervical cancer. Int. J. Gynecol. Pathol., 30 (4): 400-406, 2011.

18- JIANG Z.F., SHAO L.J., WANG W.M., YAN X.B., LIU R.Y.: Decreased expression of Beclin-1 and LC3 in human lung cancer. Mol. Biol. Rep., 39 (1): 259-267, 2012.

19- WON K.Y., KIM G.Y., LIM S.J. and KIM Y.W.: Decreased Beclin-1 expression is correlated with the growth of the primary tumor in patients with squamous cell carcinoma and adenocarcinoma of the lung. Hum. Pathol., 43 (1): 62-68, 2012. 
20- DING Z.B., SHI Y.H., ZHOU J., et al.: Association of autophagy defect with a malignant phenotype and poor prognosis of hepatocellular carcinoma. Cancer. Res., 68 (22): 9167-9175, 2008.

21- AHN C.H., JEONG E.G., LEE J.W., et al.: Expression of beclin-1, an autophagy-related protein, in gastric and colorectal cancers. APMIS, 115 (12): 1344-1349, 2007.

22- KIM H.S., LEE S.H., DO S.I., LIM S.J., PARK Y.K. and KIM Y.W.: Clinicopathologic correlation of beclin-1 expression in pancreatic ductal adenocarcinoma. Pathol. Res. Pract., 207 (4): 247-252, 2011.

23- CAO Y. and KLIONSKY D.J.: Physiological functions of Atg6/Beclin 1: a unique autophagy-related protein. Cell. Res., 17 (10): 839-849, 2007.

24- Pathologists' Guideline Recommendations for Immunohistochemical Testing of Estrogen and Progesterone Receptors in Breast Cancer. Breast. Care. (Basel), 5 (3): 185-187, 2010.

25- WOLFF A.C., HAMMOND M.E., HICKS D.G., et al.: Recommendations for human epidermal growth factor receptor 2 testing in breast cancer: American Society of Clinical Oncology/College of American Pathologists clinical practice guideline update. J. Clin. Oncol., 31 (31): 3997-4013, 2013

26- Won K.Y., Kim G.Y., Kim Y.W., Song J.Y. and Lim S.J.: Clinicopathologic correlation of beclin-1 and bcl-2 expression in human breast cancer. Hum. Pathol., 41 (1): 107-112, 2010.

27- BAUER K.R., BROWN M., CRESS R.D., PARISE C.A. and CAGGIANO V.: Descriptive analysis of estrogen receptor (ER)-negative, progesterone receptor (PR)negative, and HER2-negative invasive breast cancer, the so-called triple-negative phenotype: A population-based study from the California cancer Registry. Cancer, 109 (9): 1721-1728, 2007.

28- SOTIRIOU C. and PUSZTAI L.: Gene-expression signatures in breast cancer. N. Engl. J. Med., 360 (8): 790-800, 2009.

29- RAKHA E.A., REIS-FILHO J.S. and ELLIS I.O.: Combinatorial biomarker expression in breast cancer. Breast. Cancer. Res. Treat., 120 (2): 293-308, 2010.

30- LIN N.U., CLAUS E., SOHL J., RAZZAK A.R., ARNAOUT A. and WINER E.P.: Sites of distant recurrence and clinical outcomes in patients with metastatic triplenegative breast cancer: High incidence of central nervous system metastases. Cancer, 113 (10): 2638-2645, 2008.

31- SMID M., WANG Y., ZHANG Y., et al.: Subtypes of breast cancer show preferential site of relapse. Cancer Res., 68 (9): 3108-3114, 2008.

32- BERNS E.M., FOEKENS J.A., VOSSEN R., et al.: Complete sequencing of TP53 predicts poor response to systemic therapy of advanced breast cancer. Cancer. Res., 60 (8): 2155-2162, 2000.

33- BOMBONATI A. and SGROI D.C.: The molecular pathology of breast cancer progression. J. Pathol., 223 (2): 307-317, 2011.

34- BERGH J., NORBERG T., SJOGREN S., LINDGREN A. and HOLMBERG L.: Complete sequencing of the p53 gene provides prognostic information in breast cancer patients, particularly in relation to adjuvant systemic therapy and radiotherapy. Nat. Med., 1 (10): 1029-1034, 1995.

35- BOSCH A., EROLES P., ZARAGOZA R., VINA J.R. and LLUCH A.: Triple-negative breast cancer: Molecular features, pathogenesis, treatment and current lines of research. Cancer. Treat. Rev., 36 (3): 206-215, 2010.

36- MATHEW R., KARANTZA-WADSWORTH V. and WHITE E.: Role of autophagy in cancer. Nat. Rev. Cancer., 7 (12): 961-967, 2007.

37- KOBAYASHI S. CHOOSE DELICATELY and REUSE ADEQUATELY: The Newly Revealed Process of Autophagy. Biol. Pharm. Bull., 38 (8): 1098-1103, 2015.

38- GLICK D., BARTH S. and MACLEOD K.F.: Autophagy: Cellular and molecular mechanisms. J Pathol., 221 (1): 3-12, 2010.

39- FENG Y., HE D., YAO Z. and KLIONSKY D.J.: The machinery of macroautophagy. Cell. Res., 24 (1): 24-41, 2014.

40- TONG Y., YOU L., LIU H., et al.: Potent antitumor activity of oncolytic adenovirus expressing Beclin-1 via induction of autophagic cell death in leukemia. Oncotarget, 4 (6): 860-874, 2013.

41- CECCONI F. and LEVINE B.: The role of autophagy in mammalian development: Cell makeover rather than cell death. Dev. Cell., 15 (3): 344-357, 2008.

42- SHEN S., KEPP O. and KROEMER G.: The end of autophagic cell death? Autophagy, 8 (1): 1-3, 2012.

43- QU X., YU J., BHAGAT G., et al.: Promotion of tumorigenesis by heterozygous disruption of the beclin 1 autophagy gene. J. Clin. Invest., 112 (12): 1809-1820, 2003.

44- KUSAMA Y., SATO K., KIMURA N., MITAMURA J., OHDAIRA H. and YOSHIDA K.: Comprehensive analysis of expression pattern and promoter regulation of human autophagy-related genes. Apoptosis, 14 (10): 1165-1175, 2009.

45- YUE Z., JIN S., YANG C., LEVINE A.J. and HEINTZ $\mathrm{N}$.: Beclin 1, an autophagy gene essential for early embryonic development, is a haploinsufficient tumor suppressor. Proc. Natl. Acad. Sci. USA, 100 (25): 15077 15082, 2003.

46- KANG R., ZEH H.J., LOTZE M.T. and TANG D.: The Beclin 1 network regulates autophagy and apoptosis. Cell Death Differ., 18 (4): 571-580, 2011.

47- ZHOU Y., RUCKER E.B., $3^{\text {rd }}$ and ZHOU BP.: Autophagy regulation in the development and treatment of breast cancer. Acta Biochim Biophys Sin (Shanghai), 48 (1): 60-74, 2016.

48- CHEN Y., LU Y., LU C. and ZHANG L.: Beclin-1 expression is a predictor of clinical outcome in patients with esophageal squamous cell carcinoma and correlated to hypoxia-inducible factor (HIF)-1alpha expression. Pathol. Oncol. Res., 15 (3): 487-493, 2009.

49- MIRACCO C., CEVENINI G., FRANCHI A., et al.: Beclin-1 and LC 3 autophagic gene expression in cutaneous melanocytic lesions. Hum. Pathol., 41 (4): 503-512, 2010.

50- LIU J.L., CHANG K.C., LO C.C., CHU P.Y. and LIU C.H.: Expression of autophagy-related protein Beclin-1 in malignant canine mammary tumors. BMC Vet Res., 9: $75,2013$. 
51- YUE W., HAMAI A., TONELLI G., et al.: Inhibition of the autophagic flux by salinomycin in breast cancer stemlike/progenitor cells interferes with their maintenance. Autophagy, 9 (5): 714-729, 2013.

52- GRANDER D. and PANARETAKIS T.: Autophagy: Cancer therapy's friend or foe? Future. Med. Chem., 2 (2): 285-297, 2010.

53- HE C. and KLIONSKY D.J.: Regulation mechanisms and signaling pathways of autophagy. Annu. Rev. Genet., 43: 67-93, 2009.

54- HSU C.M., TSAI Y., WAN L. and TSAI F.J.: Bufalin induces $\mathrm{G} 2 / \mathrm{M}$ phase arrest and triggers autophagy via the TNF, JNK, BECN-1 and ATG8 pathway in human hepatoma cells. Int. J. Oncol., 43 (1): 338-348, 2013.

55- MIRACCO C., COSCI E., OLIVERI G., et al.: Protein and mRNA expression of autophagy gene Beclin-1 in human brain tumours. Int. J. Oncol., 30 (2): 429-436, 2007.

56- WANG B., FAN X., MA C., LEI H., LONG Q. and CHAI Y.: Downregulation of KDM4A Suppresses the Survival of Glioma Cells by Promoting Autophagy. J. Mol. Neurosci., 60 (2): 137-144, 2016.

57- CHEN Y., WANG X., WANG G., et al.: Integrating multiple omics data for the discovery of potential Beclin1 interactions in breast cancer. Mol. Biosyst, 13 (5): 991999, 2017.

58- KIM S., JUNG W.H. and KOO J.S.: Differences in autophagy-related activity by molecular subtype in triplenegative breast cancer. Tumour. Biol., 33 (5): 1681-1694, 2012.
59- CHOI J., JUNG W. and KOO J.S.: Expression of autophagyrelated markers beclin-1, light chain $3 \mathrm{~A}$, light chain $3 \mathrm{~B}$ and p62 according to the molecular subtype of breast cancer. Histopathology, 62 (2): 275-286, 2013.

60- FUNG C., LOCK R., GAO S., SALAS E. and DEBNATH J.: Induction of autophagy during extracellular matrix detachment promotes cell survival. Mol. Biol. Cell., 19 (3): 797-806, 2008.

61- LOCK R. and DEBNATH J.: Extracellular matrix regulation of autophagy. Curr. Opin. Cell. Biol., 20 (5): 583$588,2008$.

62- GIATROMANOLAKI A., KOUKOURAKIS M.I., KOUT SOPOULOS A., CHLOROPOULOU P., LIBERIS V. and SIVRIDIS E.: High Beclin-1 expression defines a poor prognosis in endometrial adenocarcinomas. Gynecol. Oncol., 123 (1): 147-151, 2011.

63- MASUDA G.O., YASHIRO M., KITAYAMA K., et al.: Clinicopathological Correlations of Autophagy-related Proteins LC3, Beclin-1 and p62 in Gastric Cancer. Anticancer. Res., 36 (1): 129-136, 2016.

64- WANG M.C., WU A.G., HUANG Y.Z., et al.: Autophagic regulation of cell growth by altered expression of Beclin 1 in triple-negative breast cancer. Int. J. Clin. Exp. Med., 8 (5): 7049-7058, 2015.

65- AITA V.M., LIANG X.H., MURTY V.V., et al.: Cloning and genomic organization of beclin 1 , a candidate tumor suppressor gene on chromosome 17q21. Genomics, 59 (1): 59-65, 1999.

66- REIS-FILHO J.S. and TUTT A.N.: Triple negative tumours: A critical review. Histopathology. 52 (1): 108-118, 2008.

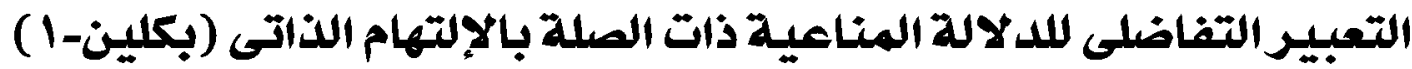

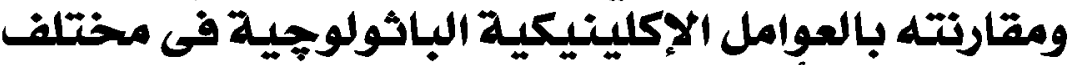

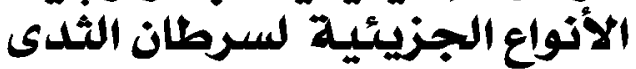

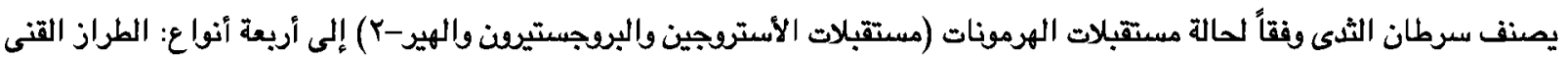

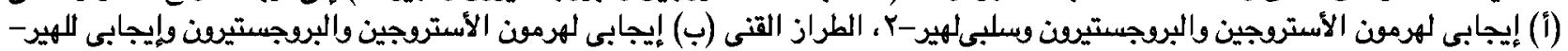

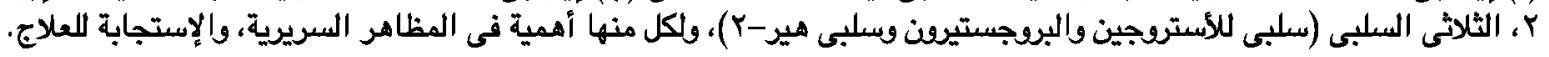

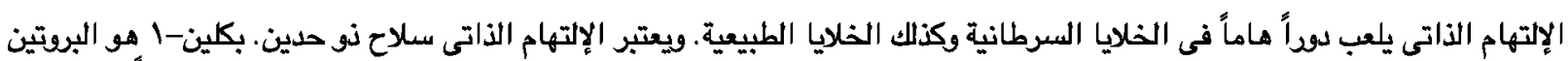

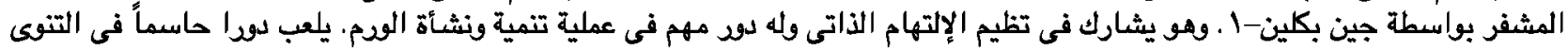
في عملية الإلتهام الذاتى.

$$
\text { يهذف هذا البحث إلى دراسة علاتة بكلين-1 ودرجة ظهوه مع البيانات الإكلينيكية فى مختلف أنقاع سرطان الثىى. }
$$

وفى هذه الدراسة وجد أن النوع الثانى السلبى لسرطان الثّى كان الاكثر عدوانية مقارنة بالأنواع الأخرى كما وجد أن الدلالة المناعية

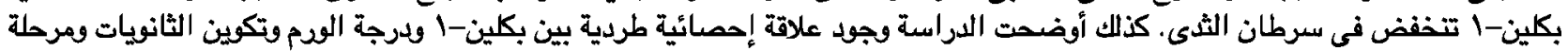
الومث ومختف الأنواع الجزينية.

ونستنتج من هذه النتائج أن الإفراط في ظهرد بكلين-1 في حد ذاته ينبئ بالطبيعة البيولوجية العلوانية اللوم. لذلك يعتقد أنه يمكن إستخدام

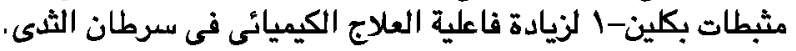

